\title{
CESARSTWO ŁACIŃSKIE W OCZACH POLSKICH DZIEJOPISÓW OD JANA DŁUGOSZA DO MACIEJA STRYJKOWSKIEGO
}

\author{
ZDZISŁAW PENTEK
}

ABSTRACT: Zdzisław Pentek, Cesarstwo Łacińskie w oczach polskich dziejopisów od Jana Długosza do Macieja Stryjkowskiego (The Latin Empire in the eyes of Polish historians from Jan Dtugosz to Maciej Stryjkowski).

Balcanica Posnaniensia. Acta et studia, XX, Poznań 2013, Wydawnictwo Instytutu Historii UAM, pp. 41-45, ISBN 978-83-63047-36-1, ISSN 0239-4278. Polish text with a summary in English.

Zdzisław Pentek, Uniwersytet im. Adama Mickiewicza, Instytut Historii, ul. Św. Marcin 78, 61-809 Poznań.

Jak wyglądała recepcja ruchu krucjatowego w Polsce mniej więcej wiadomoํ. Nie lepiej prezentuje się zainteresowanie wyprawami krzyżowymi widziane przez polskich dziejopisów okresu średniowiecza lub wieku szesnastego. Są to fragmentaryczne informacje, zapewne dalekie echa tego, co docierało do Polski. Inne sprawy, to jakość i wiarygodność przekazów. Nie są one wolne od przekłamań chronologicznych, nie wspominając już usterkach innej natury. Zatem pragnę zając się odbiorem i ewentualną wiedzą naszych kronikarzy odnośnie Cesarstwa Łacińskiego (1204-1261) od czasów jego powstania, aż do pism Macieja Stryjkowskiego.

O powstaniu tego przedziwnego państwa, owocu IV krucjaty, które wyłoniło się nieoczekiwanie na gruzach Konstantynopola i resztek państwa bizantyńskiego zdecydowali baronowie Franków oraz wodzowie weneccy. Ostatecznie, w marcu 1204 roku dokonano wstępnych ustaleń odnośnie defragmentacji Bizancjum, a po zdobyciu Królowej Miast w połowie kwietnia tego roku, nowe państwo utworzono w maju 1204 roku oraz wybrano Baldwina z Flandrii na cesarza.

Jedyny z naszych kronikarzy, który żył i działał w czasach narodzin Cesarstwa, Mistrz Wincenty, swoją uwagę skupił na wydarzeniach geograficznie najbliższych

\footnotetext{
${ }^{1}$ Mikołaj Gładysz, Zapomniani krzyżowcy. Polska wobec ruchu krucjatowego w XII-XIII wieku, Warszawa 2002. W tym zestawieniu pomijam takich pisarzy, którzy nie pisali w ogóle o Cesarstwie Łacińskim, jak np. Janko z Czarnkowa, Marcin Bielski (Kraków 1551).
} 
sobie. Zatem nic nie znajdziemy $\mathrm{w}$ tym pomniku polskiej historiografii początku XIII w.

Jan Długosz, bez wątpienia jeden z największych dziejopisów 15.wiecznej Europy, pomimo że głównie zajmował się sprawami rodzimej historii, przelotnie napomyka o kwestiach wypraw krzyżowych, które przebrzmiały już w XV wieku, chociaż w zagrożeniu ze strony Turków Osmańskich dopatrywano się niebezpieczeństwa i na wszelki wypadek szumnie mówiono o nowych krucjatach, tym razem przeciwko Osmanom. W swej Kronice, Długosz odnośnie wydarzeń roku 1200 zanotował:

Constantinopolis Grecorum civitas, in qua tunc Askarius imperabat, a Venetis et Francis capitur. [...] Aschkarius autem Constantinopolitans imperatur capta urbe versus Ponticum mare Tersonum transiit, et abinte postea Gallaciam alis Halicziensem provinciam, que est pars Russia haetermus sub Polonorum Regno consistens, pervenit et a Romana Russie duce benigniter et humane susceptus, tractatus atque habitus aliquanto tempore illic permansit. ${ }^{2}$

W tym krótkim fragmencie istotnie mamy do czynienia z postaciami historycznymi oraz wydarzeniami, które spadły na Konstantynopol, ale sprawy są nieco pomieszane. Wincenty Swoboda dowodnie przypuszczał, że wiedza Długosza oparta była przekazie Ptolomeusza z Lukki. I tak jest $\mathrm{w}$ istocie ${ }^{3}$. Przyjrzymy się chronologii zdarzeń wedle Długosza. Miasto zajęto siłami krucjaty wpierw w końcu lipca 1203 roku, a następnie ponownie w kwietniu 1204 roku. I o tym pisał Długosz, nie zaś o roku 1200. Cesarzem bizantyńskim w 1200 roku lub raczej wedle poprawnej chronologii do końca lipca tego roku 1203 był Aleksy III Angelos, następnie przywrócony na urząd Izaak II i jego syn Aleksy IV od sierpnia 1203 roku do stycznia/lutego 1204 roku. Wzmiankowany „Askarius” to ponad wszelką wątpliwość jeden z braci Konstantyn lub Teodor Laskarysowie, pierwszy z cesarzy bizantyńskich, któremu nie było dane rządzić w zdobytym przez krzyżowców mieście. Zapewne tradycja o epizodycznych rządach (styczeń/luty-połowa kwietnia 1204 roku) Aleksego V Murzuflosa nie okazała się trwała, stąd mowa tylko o „Askariusie”, czyli jednym z Laskarysów, a jeśli przyjąć, że to Teodor, to rządził on 1221 roku. Bardziej zajmująca jest kwestia: rzekomo dokąa zbiegł ów „Askarius”? Z relacji Długoszowej wynika, że cesarz skierował się przez Morze Czarne (Morze Pontyjskie) do Trapezuntu (Tersona), a potem do „Galacji”, którą miało być Księstwo Halickie. Jak wiadomo, Teodor Laskarys udał się do Nikei i założył tam nowe państwo bizantyńskie, znane jako Cesarstwo Nikejskie. Nie można jednak wykluczyć, że Laskarys znalazł się w Trapezuncie, ale jak to połączyć z rzekomym jego pobytem w Księstwie Halickim? Zatem, o kim może być mowa? Hipotezy, przy tak niewiarygodnych przesłankach mogą być co najmniej dwie. Pierwsza, że Długosz oparł się na wiadomościach Ptolemeusza i potraktował

2 Ioannis Dlugossi Annales seu cronicae incliti regni Poloniae, Varsaviae 1972, ks. VI, s. 177; sprawę przekazu J. Długosza pod kątem Bizancjum, trafnie badał Wincenty Swoboda, Bizancjum w przekazach Annales Jana Dtugosza, „Balcanica Posnaniesia” 4 [1989], s. 38-41.

3 Ptolomaei Luccensis Historia ecclesiastica nova, Rerum Italicarum Scriptores, ed. L. Muratori, t. XI, Mediolani 1727, kol. 1119. 
je poważnie, bo sprawa dotyczyła Polski, która została tu przedstawiona w dobrym świetle. Druga, że doszło do pomylenia osób i spraw w narracji. I wedle mnie jest to możliwe, ale nie jest do udowodnienia. Za rządów cara Kałojana (1197-1207) z dworu bułgarskiego usunięto wszelkich pretendentów, którzy mogliby wchodzić w drogę nieobliczalnemu carowi. Wśród tych, którzy opuścili Bułgarię byli bracia Aleksander i Iwan Asen, synowie Asena I. Co się z nimi działo w czasie wygnania, nie wiadomo. Po zamordowaniu Kałojana (1207) jego następca Borił ponosił porażki z łacinnikami dotąd, aż bojarstwo postanowiło go usunać w 1217 roku. Wówczas na tron zaproszono Iwana Asena, który przybył do Bułgarii wraz ...z ruską drużyną. Owa ruska drużyna, może poświadczać (o ile to pewne, iż w ogóle była i to ruska), że któryś w książąt, władców z Bizancjum lub ogólniej Półwyspu Bałkańskiego był na Rusi i przyprowadził tę drużynę. Wobec tego, może to poświadczać ewentualną obecność Iwana Asena na ziemiach ruskich, ale nie jest dowodem potwierdzającym niezbicie, że ów „Askarius” jest równoznaczny z Iwanem Asenem. Mgliste losy w czasie wygnania mogą być zgodne z rzekomym miejscem pobytu „Askariusa”, ale powtarzam, nie musza. ${ }^{4}$ Jest też trzecie wyjście, po prostu rzecz dotyczy dwóch różnych osób, a niektóre wątki, choć podobne, nie są związane ze sobą.

Jan Długosz pod rokiem 1237 zapisał także, że papież Grzegorz IX pragnął rękoma francuskiego monarchy Ludwika IX wyswobodzić Konstantynopol, jak onegdaj zwano Bizancjum. Wspomniany w tym fragmencie Wilhelm (zm. 1251), biskup Modeny, jako papieski poseł na dwór francuski, istotnie, pojechał do Francji w 1236 roku. Zasadnicze pytanie, które rodzi się odnośnie tego ustępu, brzmi - z czyjej niewoli Grzegorz IX zamierzał wyzwalać Konstantynopol? Odpowiedź jest prosta - z niczyjej niewoli. Tu nie chodzi o wyswobodzenie Konstantynopola, lecz o wsparcie łacinników obleganych w latach 1235 i 1236 przez cesarza nikejskiego Jana Vatatzesa i cara Bułgarii Iwana II Asena. Zatem wiadomość ta, choć chronologicznie obarczona pewnym defektem wcale nie jest daleka od prawdy. ${ }^{5}$

Pod rokiem 1274 Długosz zanotował, że w Konstantynopolu rządził już Michał Paleolog i nic nie dowiadujemy się o zaistniałej zmianie politycznej, która wydarzyła się w 1261 roku.

Maciej z Miechowa (1457-1532) autor Chronica Polonorum, poświęcił niewiele uwagi - adekwatnie do tytułu dzieła - wydarzeniom marginalnym z polskiego punktu widzenia. Od Długosza przeniósł informacje z roku 1200: „Eodem anno capta Constantinopoli a Venetis et Francis. Ascarius imperator.” Zatem finalnie jest to kopia tradycji o zdobyciu miasta przez Wenecjan i Franków oraz wspomnienie o Askariusie 6 .

\footnotetext{
${ }^{4}$ Иван Божилов, Фамилята на Асеневци (1186-1460). Генеалогия и просопография, София 1985, s. 77.

${ }^{5}$ Ioannis Dlugossi Annales seu cronicae incliti regni Poloniae, Varsaviae 1972, ks. VI, s. 279-280; Lucien Auvray, Les Régistres de Grégoire IX, Paris 1899-1910, t. II, 217-218; Wincenty Swoboda, Bizancjum w przekazach Annales Jana Dlugosza, „Balcanica Posnaniesia” 4 [1989], s. 39-40.

${ }^{6}$ Mathiae de Miechovia, Chronica Polonorum, Graccoviae [!] per Hieronymum Vietorem 1521, s. 113.
} 
Nieco bardziej rozbudowaną jest wersja Macieja Stryjkowskiego (ok. 1547$-1593)^{7}$, który napisał:

\begin{abstract}
A tak roku Pańskiego 1200 Wenetowie i Francuzowie, morzem przyciagnąwszy, Konstantynopole ubiegli i opanowali. A cesarz grecki Askarius uciekł do Tersony, a stamtąd do Halicza, który Grekowie Galacyą zowią, przyszedł [do] stołecznego miasta natenczas górnych ruskich ziem i był wdzięcznie i uczciwie przyjęty i opatrzony od Romana, książęcia ruskiego, który się też monarchą ruskim pisał. Tym tedy sposobem łacinnicy opanowali cesarstwo greckie i jego majestat.

Baldwinus flanderski, pierwszy łacinnik, w Konstantynopolu panował, ale nie był spełna roku i umarł.

Henrykus, jego brat, ten dobrze sprawował cesarstwo, dziewkę dziedziczną po sobie zostawił.

Piotr Ansyjodorski po żenie wziął sceptrum cesarskie. A gdy Robertus, syn jego, w Rzymie umarł, Grekowie zasię dostali stolca i sceptrum konstantynopolitańskiego pod łacinniki.

Michał Paleologus był okrutny, przeto go lud pospolity nie dał chować po śmierci.
\end{abstract}

Chronologia i losy „Askariusa” są wzorowane na przekazie Jana Długosza ${ }^{8}$. To nie budzi wątpliwości. Dalszy ciąg relacji jest oparty na bliżej nieznanym dziele lub dziełach. Baldwinus, to rzecz jasna Baldwin I, który istotnie po niespełna roku panowania wpadł do bułgarskiej niewoli pod bitwie pod Adrianopolem (kwiecień 1205) i rzeczywiście w niej zmarł, ale kiedy dokładnie nie jest wiadomym. Maciej Stryjkowski wiedział o rodzinnych powiązaniach pomiędzy Baldwinem, a Henrykiem. Byli braćmi. Słuszna jest także ocena rządów Henryka (1206-1216). Zajmująca jest też wiedza dziejopisa odnosząca się do nieznanej z imienia córki cesarza Henryka, którą wydano za Aleksego Sława, lennika i stronnika tego pierwszego. Po śmierci Henryka, baronowie Cesarstwa postanowili zaprosić na tron hrabiów Hainaut. Najbliższą krewną zmarłego cesarza była jego siostra Jolanta, która poślubiła Piotr z Courtenay. Trafnie zatem napisał Stryjkowski, że Piotr został cesarzem z tej racji, iż był mężem Jolanty. Piotr jednak zaginął w niewoli podczas drogi do Konstantynopola, wobec czego nowym władcą został nieudolny Robert, który zmarł w 1228 roku w Rzymie uciekłszy z Konstantynopola w 1227 roku. U Stryjkowskiego następuje znaczny przeskok w chronologii, który pominął lub nie wiedział o rządach regentów Cesarstwa, panowaniu Jana z Brienne i Baldwina II. Pisarz nie datuje, kiedy upadło państwo łacinników nad Bosforem, ale widocznym znakiem zmiany rządów jest panowanie Michała VIII Paleologa, na którego okrutne rządy powołuje się dziejopis. W tej ostatniej kwestii należy powiedzieć, że Michał VIII mimo niewątpliwych zasług dla odnowienia Cesarstwa Bizantyńskiego prowadził dość bezwzględną politykę dynastyczną, a przez wielu był postrzegany jak uzurpator dążący do zakończenia schizmy. W 1261 roku wyeliminował on z gry o tron małoletniego Jana IV Laskarysa, syna Teodora II, po

${ }^{7}$ Maciej Stryjkowski, O poczqtkach, wywodach, dzielnościach, sprawach rycerskich $i$ domowych sławnego narodu litewskiego, żemojedzkiego i ruskiego, przedtym nigdy od żadnego ani kuszone, ani opisane, z natchnienia Bożego a uprzejmie pilnego doświadczenia, opracowała Julia Radziszewska, Warszawa 1978, s. 464-465.

${ }^{8}$ Komentarz redakcyjny jest odmienny od przyjętego w wersji Długosza, tu Askarius jest Aleksym III, Maciej Stryjkowski, O poczqtkach, s. 652. 
prostu wyłupiając mu oczy i tym samym stał się jednowładcą. Wprawdzie cesarz został obłożony ekskomuniką, ale w 1267 roku została zeń zdjęta i ponownie nałożona. W 1272 roku koronował, jeszcze za swego życia, syna Andronika. Jednak te i inne zaszłości budziły kontrowersje duchowieństwa (kwestia unii lyońskiej), później rodziny oraz sprzeciw ludności, które przełożyły się na to, że po śmierci (11 XII 1282) w Pachomion został on pochowany, bez specjalnej pompy i obecności duchowych. ${ }^{9}$

Nasi pisarze działający w XV i XVI w. dysponowali zatem pewną szablonową wiedzą, wspartą o niezbyt rozpoznane przez nas źródła, które trafiły z pewnością nie w jednym zastrzyku wiedzy, co widać po ewolucji przekazów. Jak zaznaczyłem na wstępie, informacje te były fragmentaryczne, niepełne, a podnoszone wątki być może zostały pomieszane. Ale krótkotrwałe Cesarstwo Łacińskie nie zasługiwało już w XV czy XVI wieku na szczególną recepcję i nie pobudzało do większego zainteresowania niż na to zasługiwało.

\title{
THE LATIN EMPIRE IN THE EYES OF POLISH HISTORIANS FROM JAN DŁUGOSZ TO MACIEJ STRYJKOWSKI
}

\author{
Summary
}

Until the times of Jan Długosz Polish historians had not mentioned anything about the Latin Empire. It was Jan Długosz in his Chronicle who gave reliable and even extensive, though fragmentary, and slightly mixed information about it. He presented a summary of it and copied it with some chronological mistakes from Maciej of Miechów. In the second part of the $16^{\text {th }}$ century, this information was repeated by Maciej Stryjkowski in his work: On the Beginnings. Stryjkowski enriched Długosz's information with new one, coming from an unknown source. The information about the Latin Empire provided by the Polish chroniclers was fragmentary and distorted. The short-lived Latin Empire in the $15^{\text {th }}$ and the $16^{\text {th }}$ century did not deserve any special interest.

${ }^{9}$ Georgios Pachymeres, De Michaele et Andronico Palaeologis. Libri XIII, CSHB, ed. B. G. Niebuhr, Bonn 1853, s. 531-532; Teresa Wolińska, Michat VIII [w:] Paleologowie, Warszawa 2011, s. 22-25. 
